ARTICLE

Received 1 Jul 2016 | Accepted 4 May 2017 | Published 27 Jun 2017

\title{
Integrity and justice: what is required of free market participants?
}

David Bauman ${ }^{1}$

\begin{abstract}
The purpose of this article is to present an account of integrity and justice in a free market. The article seeks to answer the question, "When evaluating integrity, what does justice require of free market participants?" using historical, philosophical, and economic perspectives. The answer to this question can guide researchers and practitioners to better evaluate market participants and their integrity or counterfeit integrity. Market participants include corporations, investors, employees, communities, unions, consumers and governments within the context of democratic institutions. The article first outlines an account of integrity that explains the connection between integrity attributions and the moral community. Adam Smith's ideal model of a free market and several critiques from a justice perspective are then presented. A review of different accounts of justice follows and it is argued that defining justice as desert (that is, give others what they are owed) avoids irreconcilable justice accounts and increases transparency. Using the accounts of integrity and justice situated in a free market, a description is provided of the implications of these accounts by analyzing how two companies, Apple and McDonald's, demonstrate integrity or counterfeit integrity in regards to the justice issues of wealth inequality and low wages. This article is published as part of a collection on integrity and its counterfeits.
\end{abstract}

\footnotetext{
${ }^{1}$ College of Business and Economics, Regis University, Denver, Colorado, USA
} 


\section{Integrity in the context of community}

ntegrity is a concept with a variety of meanings and uses. According to Beebe, one of the earliest definitions of integrity denoted the state of being untouched. He states, "Tag, its Sanskrit root, as the game we still call by this name implies, means to touch or handle. Out of this root come words like tact, taste, tax, and contaminate. Integ means not touched or handled" (Beebe, 1992: 6). The Latin form of the word integer meant fresh, unimpaired, virgin, as well as whole and complete.

Eventually the moral term integritas entered the Latin language. The Roman philosopher Cicero used the word while prosecuting the Sicilian governor Gauis Verres for embezzling. Cicero (1928/c. 70 BCE) calls for ethical leadership when he states, "nor can a greater disaster come upon us all than a conviction, on the part of the Roman people, that the Senatorial Order has cast aside all respect for truth and integrity, for honesty and duty [... rationem veritatis, integratatis, fidei, religionis ab hoc ordine abiudicar]". Later Seneca uses the word integritum as a moral quality of someone he would sponsor. In De Beneficiis Seneca (1989/c. 65) states, "I shall choose a man who is upright [integritum], sincere, mindful, grateful, who keeps his hands from another man's property, who is not greedily attached to his own, who is kind to others". Note that both of these ancient sources describe integrity as a trait that the community expects of its leaders and citizens.

Our modern use of the word similarly relies on these early moral foundations. The New Oxford American Dictionary defines integrity as "(1) The quality of being honest and having strong moral principles; moral uprightness; (2) The state of being whole and undivided; the condition of being unified, unimpaired, or sound in construction" (2005). The American Heritage Dictionary defines integrity as "(1) steadfast adherence to a strict moral or ethical code, (2) the state of being unimpaired; soundness, (3) the quality or condition of being whole or undivided; completeness" (Wordnik.com, n.d.).

Like their ancient roots, these definitions describe an uncorrupted (or unimpaired or whole) person who is committed to moral principles. Bauman refines the definition when he argues that to have moral integrity one must have identity-conferring commitments to moral values (2013). The nature of a commitment is to define one's identity, and this part of his definition captures the "wholeness" aspect of integrity attributions. For a person of integrity to act dishonestly is for her to deny her deepest commitment-to deny herself. On Bauman's account, moral integrity requires a commitment that is tied to an uncorrupted self identity.

The object of this commitment focuses on the moral aspect of integrity attributions. The link between individual integrity (for example, commitments) and the community of other rational humans is moral values. Bauman (2013: 421) defines moral values as "those values that the human community in general has a right to expect its members to practice". Philosophers have noted the connection between morality and a person's relationship with other rational humans. Williams (1985) explains that the moral community of humans, of which all rational humans are members, has an instrumental need for reliable negative action (for example, we won't lie to each other) and positive action (for example, we will help each other in emergencies) for it to function and survive. Wallace (1978) also observes that community-oriented character traits, which are loosely equated to a commitment to moral values, are essential for communities to function. The benefits of trust, efficiency and survival are instrumental reasons that justify the importance of moral values and also justify community members expecting each other to not violate these values.

As an ethicist, Adam Smith based his arguments for individual moral obligations on the expectations that humans have of each other. Smith (2002) constructs an account of justice on the natural reaction of resentment toward those who violate individual rights. He states, "There can be no proper motive for hurting our neighbor, there can be no incitement to do evil to another, which mankind will go along with, except just indignation for evil which that other has done to us" (2002, II.\$II.Ch2.1, p. 96).

Smith argues that while individuals naturally seek their own well being over the well-being of others, the human community does not share their self-interested perspective. According to Smith (2002), one needs to take the perspective of an "impartial spectator" to objectively evaluate one's own self-interested perspective. Only then can the agent objectively understand an individual's rights and their reactions to his/her actions. Smith explains that if an individual harms others in pursuit of personal wealth, the community members "sympathize with the natural resentment of the injured, and the offender becomes the object of their hatred and indignation" (2002, II. \$II.Ch2.1, p. 98). The community reaction checks individual behavior and protects the rights of all individuals.

While Bauman's account of moral integrity focuses on individual commitment and shared basic moral values, Robinson expands integrity to an organizational level that encompasses identity, taking responsibility for values, and deliberating with others about shared narratives (2016: 26-27). He conceptualizes a "practice of integrity" involving individuals and organizations dialoging about a better future. It is a complex account that seeks to address the complexity of the modern business world (p. 93). According to Robinson, the practice of integrity anchors itself in law, professions, industries, and the particular moral values of respect and justice. Robinson states, "Practising integrity in business demands taking responsibility for critically relating to each of these anchor points in developing: a narrative of values, purpose and worth; a public account of meaning and practice; and creative responsive practice" (2016: 123). The integrity dynamic requires creative dialog and constructive relationships for stakeholders who take responsibility for themselves and the whole.

These accounts of integrity vary in focus (for example, individual or corporate) and content (for example, moral values or anchors of responsibility). The ancient, individual, and corporate accounts of moral integrity do intersect at two points that will define integrity for the purposes of this article. First, moral integrity requires a commitment by the individuals and/or parties who interact in a community. The commitment could be to specific moral values such as honesty or to taking responsibility for creating a more inclusive market. The accounts above recognize that integrity requires a deep commitment as opposed to a mere preference or a temporary objective. Moral integrity that generates trust seems to require a deep commitment that is consistently demonstrated.

Second, moral integrity requires the commitment to be to a moral value that is expected by the community. Bauman (2013) argues that moral integrity requires a commitment to basic moral values and that these are grounded in the moral expectations of community members. These values are those that all community members are expected not to violate such as honesty, keeping promises, and respecting others. Smith explains that the human community has natural and justified resentment toward those who violate the natural rights of other citizens. Robinson expands on the objects of commitment to include several anchor points such as the law, the community, and moral values such as justice and respect (2016: 122-123). These accounts recognize that respecting some moral values are necessary for integrity attributions. For example, a CEO who violates a promise would not be considered to have integrity. Violating basic moral values 
disqualifies an integrity attribution, just as telling a lie disqualifies an attribution of honesty.

For the purpose of this article I assume that integrity (that is, moral integrity) requires a deep commitment to basic moral values that are grounded in the expectations of the human community. The community, which can include individuals, corporations, government institutions, and other stakeholders, expects its members to not violate basic moral values. Following Smith and Robinson, I also assume that the basic moral values include justice. Additionally, I assume that integrity does not require altruism. As Robinson states, "Integrity is not about altruism, but about taking responsibility for purpose and values such as justice" (2016: 255). Narrowly construed, integrity requires not compromising moral values rather than creating a more generous world.

Finally, people may claim to have integrity when they actually do not meet the standards described above. Robinson explains that counterfeit integrity is an imitation that "seeks to mimic behavior without necessarily taking responsibility for the meaning of that practice" (2016: 54). While agents may claim that they have integrity, their actual behaviors reveal their true commitments. Robinson explains that whereas BP presented itself as an environmentally concerned company, evidence revealed a primary focus on profits and production (2016: 247-248). Counterfeit integrity appears when an agent's claims do not match their actions and responsibilities.

Because integrity and justice require a community of reference, I next describe the characteristics of an ideal free market and the justice problems in our actual markets. My description of free market characteristics leads to an analysis of what justice requires of market participants. In the final section, I consider the implications of integrity and justice for market participants.

\section{Free markets: historical ideals, critiques, and justice}

What does justice require of individuals, corporations, and social institutions in a free market system? In his 1776 book An Inquiry into the Nature and Causes of the Wealth of Nations, Adam Smith describes the characteristics of an ideal market that he claims produces value and social benefits. He also describes how wealthy individuals and powerful politicians can manipulate markets for their own gain. His claims in the Wealth of Nations build on the requirements of justice outlined in his earlier book The Theory of Moral Sentiments. Writing at a time when monarchs, politicians and monopolies held significant economic power, Smith explains how average citizens can participate in a free market that supports basic rights. Since his writings, however, critics of market inequality have demanded a more just system.

Because Smith's observations of free markets and justice still influence our modern perspectives on these topics, I describe his "classical liberal" views as a starting point. I then present criticisms of actual market results and compare different accounts of what justice requires of market participants.

Smith on free markets. Smith describes three main characteristics of a free market system. They are: (1) self-interest; (2) private rather than government investment; and (3) wealth that benefits all.

The first characteristic is that self-interest motivates, humans to seek to exchange something of value for something else of greater value. Smith (1776, I.2.1) believes that to "truck, barter, and exchange one thing for another" is wired into human psychology. Rationally humans understand that we benefit from products and services created by others who can more cheaply produce them than we can. This leads to specialization. Most accountants, for example, do not make their own shoes. Instead, they study accounting and then exchange accounting skills for money and then use the money to buy shoes from those who can make shoes more cheaply.

Smith argues that rational self-interest, and not generosity or a concern for the needs of others, guides each person to exchange the value they create with others. As Smith states:

It is not from the benevolence of the butcher, the brewer, or the baker, that we expect our dinner, but from their regard to their own interest. We address ourselves, not to their humanity but to their self-love, and never talk to them of our own necessities but of their advantages (Smith, 1776, I.2.2).

The mutual reliance in the community is not based on the admirable virtues of generosity and beneficence. Instead, it is based on a rational self-interest that seeks to exchange while not violating the rights of others. On Smith's moral account, market participants who violate community expectations face resentment and punishment.

The second characteristic of a free market is that it relies on private investment of resources. Smith observed that political interference creates inefficiencies. Smith argues that individual market participants-not politicians-know best where to invest capital. Smith explains that few legislators have the specialized knowledge or motivation needed to make investments when compared to an experienced individual or group that risks capital (1776, IV.2.10).

According to Smith, the sovereign or government only has three duties: (1) to protect society from violence and invasion; (2) to protect citizens from unjust actions by other citizens and operate a system to enforce laws; and (3) to create and maintain institutions that society needs but are not financially attractive to business owners to create (for example, schools) (1776, IV.9.51). He does argue for taxes to cover state expenses and also approves of the wealthy paying more because they can afford it (1776, V.1.75). Far from being "anti-government", Smith supports responsible government to protect citizens from foreign invasion, lack of education, and unjust violations of rights $(1776, \mathrm{~V})$.

The third characteristic of a free market is increased national wealth that benefits society. When an individual seeks his/her own advantage, then he/she will necessarily "prefer that employment which is most advantageous to the society" (Smith, 1776, IV.2.3). Smith argues that creating value and competing increases wealth for the owner and society because more products are available at lower prices as individuals create more value and are rewarded with more profit. In a famous passage, Smith explains that by seeking only one's own gain, a business owner is led by "an invisible hand to promote an end which has no part of his intention" (1776, IV.2.8). According to Smith, the unintended end is the wealth and interests of society.

Free markets and justice. In practice, free market economies have created wealth, but have also created inequality. Karl Marx and Frederick Engels present a strong critique of free market injustices that are echoed today. One criticism is that employers exploit workers with low wages. Because low-skill labor is treated as a commodity, Marx and Engels argue that wages are driven down to the subsistence level: "In proportion, therefore, as the repulsiveness of the work increases, the wage decreases" (1988: 16). New machines keep workers on edge at all times and give the owners more power over their lives. After work, Marx and Engels claim that the exploitation continues from the "landlord, the shopkeeper, the pawn broker, etc" (1988: 16). 
Another criticism is that wealth and property tend to go to a small part of the population-often the owners of production. The amassing of wealth and property among a small population, though not unique to free markets, reduces the options available to average workers, such as where they can live, how much they can earn, and opportunities to progress in a career. Marx and Engels argue that dissolving private property should not worry workers who don't own much in the current system. They state, "But in your existing society, private property is already done away with for nine-tenths of the population; its existence for the few is solely because of its non-existence in the hands of those nine-tenths" (1988: 25). A modern criticism is that the "top ten percent" of Americans, for example, hold a great percentage of the wealth. Piketty and Saez observed that today, "A very large part of the rise in the top $10 \%$ income share comes from the top $1 \%$ (or even the top $0.1 \%$ ). This is largely because of the rise of top executive compensation in large U.S. corporations (both financial and nonfinancial)" (2014: 838).

Smith discusses these free market consequences briefly in The Wealth of Nations: "Wherever there is great property there is great inequality. For one very rich man there must be at least five hundred poor, and the affluence of the few supposes the indigence of the many" (1776, V.1.45). Smith is observing the historical development of societies and thus does not view these particular inequalities as unjust. But why does Smith's view of justice vary so greatly from that of Marx, Engels, and others who focus on reducing social inequality? The answer is that they hold contrasting beliefs about what justice requires.

Evaluating negative and positive justice accounts. In The Theory of Moral Sentiments, Smith describes justice as a negative concept: a just person must merely avoid violating the natural rights of others. He explains that justice is a "negative virtue, and only hinders us from hurting our neighbor" (2002, II. \$II.Ch1.9, p. 95). For example, Smith contends that, "We may often fulfill all the rules of justice by sitting still and doing nothing" (2002, II.\$II. Ch1.9, p. 96). Smith describes three laws of justice that must not be violated: "the laws which guard the life and person of our neighbor; the next are those that guard his property and possessions; and the last of all come those which guard what are called his personal rights, or what is because of him from the promises of others" (2002, II.\$II.Ch2.2, p. 98). He believes that civil government evolved because as property increased, the passion to take it from others needed to be governed. "Avarice and ambition" move the rich to take property and "hatred of labor" and "love of present ease" move the poor (1776, V.1.45). The government, therefore, enforces the laws of justice.

As society and markets matured, governments passed laws to reduce inequality and protect workers from exploitation. In response to these positive justice policies, economist Friedman (2002) and Harvard professor Nozick (2000) presented a revised negative justice account based on property rights. Nozick explains that in free markets justice is about how people voluntarily acquire possessions (for example, gift, creating it, exchange) and not how wealth is distributed (2000: 302). For example, as long as I voluntarily work for company $\mathrm{K}$ and the history of my salary does not require some type of rectification of justice (that is, $\mathrm{K}$ did not steal the money from the bank), then I justly own my salary. Examples of injustice include stealing, fraud, slavery, not allowing someone to sell their products, and not allowing them to join markets (2000: 303). In regards to distributing wealth to the poor so that inequalities are minimized, Nozick argues that this is unjust because it requires the government to take from someone who justly acquired wealth and then give it to someone who needs it. He summarizes just distributions in the following phrase: "From each as they choose, to each as they are chosen" (2000: 307)

Such a minimalist account of justice from Smith, Friedman, and Nozick appear to ignore the obligations that citizens have for the welfare of each other. I would also contend that negative justice does not sufficiently address worker exploitation and inequality because it preferences property ownership over fair treatment. Philosophers such as Rawls (1999) seek to resolve the inequality problems by defining "justice as fairness" and requiring positive action such as institutions that fairly distribute wealth. In A Theory of Justice, Rawls argues that justice as fairness requires treating all people fairly which demands more than not violating rights. He also argues that rational and unbiased citizens would choose two principles of justice. The first principle is that basic liberties would be secured for everyone (Rawls, 1999: 266). These include the right to speech, voting, bodily freedom, and conscience. By belonging to a democratic system that supports unconditional natural rights, all individuals now have certain obligations. For example, the natural duty of justice "bonds citizens generally" (1999: 100). But if these citizens agree that justice is fairness, then it ties public leaders and the privileged "even more strongly to a just scheme" (1999: 100). Justice as fairness, therefore, creates obligations between the privileged and the less privileged.

The second principle that citizens would choose requires all positions of power to be available to all people and that all social institutions be designed to distribute economic and social goods equally, unless an unequal distribution is to the advantage of everyone (1999: 266). The minimal inequality allowed serves to create incentives for people to pursue occupations that society requires. Rawls acknowledges that citizens may want humans to serve each other freely, but he understands the human tendency to neglect the interests of others (1999: 131). Rawls' requirements of justice include "equal liberty for all, including equality of opportunity, as well as an equal distribution of income and wealth" (1999: 130).

Rawls' positive justice account increases the requirements of justice for market participants. Tomasi summarizes Rawls' position as requiring the "social expression of respect" (2012: 41). Rawls' positive justice does not require equal distributions or relinquishing all private property. However, it would require government oversight and high enough taxes to support equal opportunities to author a life. Also, critics of Rawls point out that the government would need to oversee wages, productive property, and pricing to ensure that any inequalities contribute to the advantage of everyone.

One can see that the negative and positive requirements of justice differ greatly. Supporters of each account believe that rational citizens should accept their account. The negative account requires protection of basic rights while respecting freedom of economic choice among market participants. The positive account requires protecting the same basic rights and also requires community members to support an equal right for all to author a life of one's choosing through some type of distribution of goods and opportunities.

According to MacIntyre (1984: 247), reconciling these requirements of justice is not possible. He explains that Rawls' positive view makes individual needs the primary focus of justice, especially those who are disadvantaged. Rawls does not consider how the disadvantaged arrived in that state. Smith's and Nozick's negative views focus almost exclusively on the history of acquisitions, but ignore the present state of people's lives (1984: 248). MacIntyre asks, "For how can a claim that gives priority to equality of needs be rationally weighed against one which gives priority to entitlements" (1984: 249)? As framed by both sides, the requirements of justice have strong moral justification (for 
example, rights and fairness/equality), but they cannot be reconciled without compromising their primary justification. In terms of market participants and integrity, adopting either view of justice requires those with the opposing view to pay a price for its implementation; either by allowing great social needs to go unmet or by increasing the distribution of property.

Justice as desert. Faced with this impasse, I propose a justice account that relies on community expectations, much like the integrity account above. MacIntyre (1984: 249) proposes the community-based justice requirement of desert. Community members regularly distinguish between who deserves what he/she has earned and who does not deserve their poverty and unequal treatment. According to MacIntyre (1984: 250), "the notion of desert is at home only in the context of a community whose primary bond is a shared understanding both of the good for man and of the good of that community and where individuals identify their primary interests with reference to those goods". On the basis of the review above, Rawls, Nozick, and Smith do not directly factor in the good of a community, but rather focus on justice as securing individual freedoms and goods.

Another way of articulating the concept of justice as desert is, "Give others what they are owed." Unlike the positive view, the desert standard considers the history and merit of a person's actions and circumstances. Unlike the negative view, the standard considers a person's present circumstances of prosperity or need.

One could object that the desert standard allows financial inequality, which is limited by Rawls' insistence that inequality must be to the advantage of all. A problem I see with Rawls' account is that it appears to ignore how people arrived in their circumstances and then attempts to equalize outcomes from an arbitrary starting point. Adopting the "give others what they are owed" standard could require market participants within a democratic context to care for the disadvantaged based on each person's history and current circumstances. Community members could be legally required to pay taxes, offer fair wages, and provide other community determined goods.

An objection from the negative view imagines that the government agencies required to enforce owing relationships would interfere in efficient markets. This objection, however, assumes that the government is the primary institution to hold participants accountable. In a desert view of justice, participants could be required to hold each other accountable for giving what is owed while the government would arbitrate disputes based on the merits of each party's claims. Also, citizens in a democratic context can pass laws that lead to the community's shared good. If a law requires safety equipment, pollution controls, or free healthcare for the good of the community, then the participants must give what is owed as defined by that law. Government representatives must fulfill their roles vigorously just as the other market participants.

Adopting the desert account for free market participants can avoid the conflict of the negative and positive accounts while grounding justice in relationships among market participants. In light of the discussion above, I propose two requirements of justice as desert. In line with both positive and negative justice accounts, market participants must give others the respect they are owed as rational members of the community. Justice would require that community members respect each other's bodily integrity, property, freedom to exchange, freedom to apply and hold any job, and also to honor promises and contracts. Through negotiations, arbitration, and government enforcement when necessary, citizens would establish and enforce laws that protect market participants from those who would violate their rights. Market participants can also hold each other accountable for giving what is owed, such as an employee taking an employer to court for not paying wages or an employer firing an employee for lying to regulators.

A second justice as desert requirement is that market participants give what is owed to each other and to the overall community based on the merits (that is, who is owed what) of each situation. On this account, it is unjust to take more for oneself when another member or the overall community is owed more. For example, justice as desert requires an employer to pay a wage that fairly compensates the worker for the job done, and employees must give a fair day's work. If the employers and employees disagree on wages, they can negotiate on the merits of the job, the experience required, the industry, and the financial situation. If employees feel they are not being given what is owed, they can bargain as a unit or lobby their government representatives to legally require employers to pay what is owed. Employers can also argue that the wage is fair.

Justice as desert may require a constant conversation within the community so that all participants consider the merits of different claims. If one looks at market participant interactions today, many desert issues are negotiated or arbitrated on their merits such as union contracts, tax subsidies or increases, product safety requirements, and carbon emissions. MacIntyre (1984: 255) explains that maintaining the rule of law, dealing with injustice and suffering, and defending liberty must all be pursued, but that each "particular task, each particular responsibility has to be evaluated on its own merits". While justice as desert brings the community back into discussions of what is owed, negative and positive justice supporters could object that the desert view compromises rights too far.

An objection from the negative justice side would be that market participants have no obligation to "give what is owed" to support the good of the community. Friedman famously argued that, "there is one and only one social responsibility of businessto use its resources and engage in activities designed to increase its profits so long as it stays within the rules of the game, which is to say, engages in open and free competition, without deception or fraud" (2002: 133). Friedman (1970) reaffirmed his arguments in a New York Times Magazine article in which he again argued that corporations must seek profits for their owners while also playing by the rules, "both those embodied in law and those embodied in ethical custom".

While this negative justice objection recalls Smith, it ignores the community within which businesses operate. Robinson points out that Friedman's narrow role for individuals and corporations is arbitrary. He explains that Friedman provides no justification for fragmenting society into such narrow zones of influence and that such a view of corporate responsibilities, "tends to lead to a diminution of the capacity to take responsibility, to maintain awareness of the effects of practice on the social environment and to respond" (2016: 80). Defining justice as desert requires all market participants to take responsibility for their actions and for giving what is owed. I believe the desert view better reflects the dynamic interactions between market participants which often create the owing relationships involved in justice.

An objection from the positive justice side concerns the problems identified by Marx and Engels. Justice as desert may allow inequality to grow because using the merits of each situation could bias the outcomes toward those who work harder, earn more, and own more property. Also, the employer still has more power to lower wages and exploit workers. It could be argued that requiring equal distributions to all would better solve the inequity problem.

I would argue that this objection assumes that equal or nearequal distributions are more important than giving people what they are owed based on some measure of merit. While unequal and equal distributions are possible under desert, they must be 
based on the merits of what is owed given past, present, and future considerations of the individuals and the good of society. Justice as desert must base unequal distributions on a standard of merit such as need, effort, and circumstances. For example, an unemployed person who is not willing to work may not be entitled to a government payment, but being employed may require paying into an unemployment fund to provide for those in need. Each case must be determined on its merits. Also, market participants can provide for the least advantaged. "Giving others what they are owed" requires equal respect. Market participants in a democratic context may determine that citizens are owed job training, support while unemployed, healthcare, or a higher minimum wage based on their equal basic rights.

\section{Implementing justice as a function of integrity}

With the conceptual analysis of integrity and justice completed, we can answer the question, "When evaluating integrity, what does justice require of free market participants?" We can also determine two important market changes that would support these requirements.

Recall that integrity requires a commitment to basic moral values that are defined by the community's expectations. In the case of free markets, the moral community is composed of citizens, consumers, corporations, investors, local communities, and the democratic institutions that set and enforce laws. I am assuming that members expect each other to not violate basic moral values, including the requirements of justice. Also, altruistic behavior is not required to have integrity because not violating moral values and taking responsibility is enough to fulfill the necessary requirements of integrity (Robinson, 2016: 255).

Combining the definition of integrity with the two requirements of justice outlined above produces the following standard: A person or organization of integrity in a free market is committed to giving others what they are owed, which means they are committed to (1) respecting the bodily integrity, property, freedom to exchange, and promises/contracts of others, and (2) determining and giving what is owed based on the merits of each situation.

The first commitment is not new to market participants because many democratic institutions protect individuals from the disrespecting of their body, property, and freedom. Market participants, however, would need to change expectations and practices to implement the second commitment. First, market participants would need to work together to determine what is owed across a variety of situations. Industry associations, chambers of commerce, government panels, unions, and management/worker teams are examples of groups that could determine the merits of different claims. Second, participants would be expected to hold each other accountable for giving what is owed. Currently this is often done in the courts, but market participants can select other venues to determine and give what is owed. For example, the Equal Employment Opportunity Commission (EEOC) in the United States has implemented a "mediations and conciliations" program for discrimination complaints. The program achieved a success rate of $76 \%$ and saved "resources for employers, workers and the agency" to resolve injustice (what is owed) without costly litigation (EEOC, 2017).

Below I apply the integrity and justice requirements to address the concerns about wealth inequality and worker wage exploitation identified earlier. I focus on cases involving two well-known companies that face these specific issues: Apple and McDonald's.

Apple, Inc. in Ireland. In late August 2016, the European Union ordered Apple to pay almost US\$14.5 billion in taxes to Ireland. An EU commission found that, "Ireland had provided illegal state aid through an advance transfer pricing ruling that allowed Apple's Irish affiliates to pay far less than Ireland's official $12.5 \%$ corporate income tax rate on trading income" (Kadet, 2016). Apple CEO Tim Cook responded that, "Apple follows the law and we pay all the taxes we owe" (2016). He claims that Apple did not receive a special tax deal, but this is misleading. Ireland and Apple agreed that Apple would decide how much of its income would be recognized and taxed in Ireland. The unrecognized and untaxed income could then move into tax-free structures that do not sit in any state (Benner, 2016).

Cook insists that Apple pays all the taxes it owes, which is a claim of having integrity in regards to justice. According to the concept of justice as desert, it appears that Apple is paying all the taxes it owes, but not if we consider the market community in Ireland. The Irish corporate tax is $12.5 \%$, but Apple only paid $.005 \%$ in 2014 (Kadet, 2016). So while it is true that Apple paid all the taxes it owed, it owed so little because of its special arrangements. This special deal violates the first and second requirements of justice as desert. First, taxes are owed to the Irish people and Apple did not respect their claim on the $12.5 \%$ tax. Other companies had to respect this claim on their profits, while Apple did not. The result was a disparate tax burden that favored Apple, a wealthy corporation.

One could argue that the special contract with the Irish tax authority is the only contract Apple had to fulfill. This is where Apple and the Irish government violated the second requirement of justice because they did not determine what is owed based on the merits of the situation. As presented above, justice could require all relevant market participants to join the tax discussion. The larger discussion is required because what is eventually "owed" needs to be based on the merits of all the market participants.

One concern about determining merit is that it could allow any Apple stakeholder to negotiate. Is the desert model too difficult to apply because it multiplies stakeholders? Robinson addresses the multiple stakeholder concern by arguing that the relationship of the company to the other parties determines what type of responsibility attaches (2016: 81). In this case, the market participants with the greatest responsibility are the government representatives and similar multi-national corporations (for example, Microsoft and Google). These market participants can determine what corporations owe based on the merits of their cases. This does not mean that each company would receive its own tax rate, but some could receive subsidies and others may have to pay more because of the resources they use. The result could be a more just (that is, deserved) distribution of wealth across market participants, including the Irish government.

Fuerstein (2015) similarly recommends market forums to balance corporate power with the citizen's voice in contesting potentially harmful actions. He recommends that market deliberations include "formal legislative and economic forums, interactions within commercial organizations and alliances, exchanges with shareholders, and engagement with the broader community" (2015: 431). These meetings could address social concerns and how businesses can play a positive role in the market community. In regards to the second change required for desert, the meetings can also allow market participants to hold each other accountable for failing to give what is owed.

When we consider Tim Cook's integrity, his response hints at counterfeit integrity because he claims that Apple is giving what is owed when it is actually giving what is agreed. While Cook did not lie, he avoided explaining why Apple paid a tax rate of .005\% in 2014. Robinson calls counterfeit integrity "the instrumental representation of the self", wherein a market participant imitates a person with integrity to earn more admiration and profits, or to 
avoid negative press or financial loss (2016: 246). Cook appears to demonstrate counterfeit integrity in regards to paying what is owed because he is bending the truth to please shareholders and consumers.

In the Apple case, we can see how the requirements of justice as desert could minimize wealth inequality by requiring transparency and open discussions of what is owed by all participants.

Wages at McDonald's. In 2015, McDonald's Corporation paid out over $\$ 9.4$ billion in dividends and to buy back their own stock (McDonald's Corporation - 10-K 2015: 15), while the average self-reported wage of their US line workers was about $\$ 8.40$ an hour (McDonald's Average Wage, 2016). CEO Steve Easterbrook received a total compensation package of $\$ 7.9$ million in 2015 (Bomkamp, 2016). If he worked 60 hours a week for 50 weeks in 2015 , his hourly wage would be $\$ 2633.33$ an hour.

The disparity between CEO and shareholder payments and the small wage for employees seems to prove that the dynamics of free market inequality continue (Piketty and Saez, 2014). While Robinson details how integrity and justice should guide CEO compensation decisions (2016, Chapter 6), I analyze the low wage aspect of the McDonald's case and how integrity and justice as desert would address this issue. First, it appears that McDonald's is not violating any of the worker's rights covered in the first commitment to justice. It appears that employees voluntarily agree to work for the company, can quit at any time, and their contracts are honored.

The second justice requirement, however, seems to be lacking. Because of the actual payout differential for the CEO, shareholders and employees, one could argue that the executives are not committed to determining what is owed given the merits of the situation. Consider that McDonald's executives determine the dividend payout for each year (2016-\$3.61/share) and could argue that the dividend is what they owe the shareholders (NASDAQ, 2017). Executives also provide quarterly investor conference calls for investors. What appears to be missing is a meeting with line employees about what is owed.

On the desert model, the problem with low wages is that no forum exists for market participants (that is, executives, managers and workers) to discuss what is actually owed. One result is that citizens and government participants often legislate higher wages. Such legislation can ignore the merits of the situation by setting wages for millions of workers that may or may not fit the merits of the situation. For example, legally requiring a $\$ 15$ or $£ 10$ an hour minimum wage for all workers regardless of skill level or job difficulty may harm small businesses that do not have profits like McDonald's. To adapt, these businesses often consider increasing their prices, automating, or going out of business. Even with its high profits, McDonald's is installing automated order kiosks in its 14,000 American restaurants to speed ordering (Worstal, 2016).

All parties lose an opportunity to demonstrate integrity in regards to justice when relevant parties do not determine what is owed. The employee voice may be channeled through laws which reduce the freedom of market participants to negotiate. For example, it becomes illegal for workers to negotiate a wage under a minimum or living wage. It should be noted that some government bodies loosely apply the principle of giving others what they are owed by creating a graduated minimum wage. The United Kingdom, for example, requires a graduated minimum wage based on age so that a17-year old ( $£ 4.00 /$ hour) is not paid the same minimum wage as a 24 -year old (£6.95/hour) (National Minimum Wage and National Living Wage, 2017). A problem with set wages, however, is that the wage floor may have nothing to do with the employer, the employee, and the work itself-the factors that determine what is owed.

Another option is for investors to join with managers and employees to determine what wage is owed. In 2015 a McDonald's shareholder submitted a shareholder proposal that franchises pay a minimum of $\$ 11$ an hour (Securities and Exchange Commission [SEC], 2015). US corporate law, however, considers setting wages an "ordinary business operation", which is excluded from shareholder oversight (2015). Implementing justice as desert would require laws that allow shareholder intervention so that all relevant market participants can determine what is owed. Changing the law would also allow shareholders to fulfill the second market change of all relevant market participants holding each other accountable.

Finally, does McDonald's demonstrate integrity in regards to justice as desert? In terms of the first justice requirement, it appears to fulfill its contracts and does respect its workers basic rights. From a market participant perspective where justice is giving others what they are owed, the executives lack integrity. Ignoring shareholder and employee input on wages demonstrates a lack of commitment to determining and giving what is owed. Also, executives are treating different groups unequally. Executives determine what dividends are owed and what senior executives are owed, but they have not transparently engaged shareholders, managers and employees on what the average employee is owed. I do not believe McDonald's is expressing counterfeit integrity, however, because they are not claiming to pay high wages and then not paying them.

\section{Conclusion}

I have presented an account of integrity and justice based in the community of free market participants. Integrity requires commitments to basic moral values such as justice, and justice as desert requires respecting basic rights and determining what is owed based on the merits of the situation. A community-based account of integrity and justice is not difficult to comprehend because market participants in a democratic context often include institutions and laws that encourage parties to determine and give what is owed.

The challenge for market participants is to adopt the two changes explained above: to join with relevant market participants to do determine what is owed and to hold each other accountable. Both of these changes exist today in different forms. For example, industry associations establish fair trade standards for coffee and cocoa. Also, some investors create funds that reward socially responsible companies (that is, they give stakeholders what they are owed). I believe the greatest challenge for market participants is to embrace a community model of integrity and justice in place of defending positions that allow them to withhold what is owed.

Robinson describes integrity as a dynamic dialog, "with the agent (the self), with professions, between the professions, between the professions and the corporations, between corporations and the wider industry, between corporations and civil society, and between politics and civil society" (2016: 254). The concepts outlined in this article provide principles for developing integrity and justice in a dynamic dialog that avoids the conflict of rightsbased accounts. The account also offers a path for market participants to give others what they are owed which results in integrity.

\section{References}

Bauman DC (2013) Leadership and the three faces of integrity. The Leadership Quarterly; 24 (3): 414-426. 
Beebe J (1992) Integrity in Depth. Texas A\&M University Press: College Station, TX.

Benner K (2016) Fact-checking Apple's claims on EU tax ruling. The New York Times, 30 August, viewed on 7 January 2017, http://www.nytimes.com/2016/08/ 31/technology/tax-experts-check-out-arguments-from-apple-over-ruling.html? action $=$ click\&contentCollection $=$ Technology\&module $=$ RelatedCovera ge\&region $=$ EndOfArticle\&pgtype $=$ article .

Bomkamp S (2016) McDonald's CEO 2015 pay package: $\$ 7.9$ million Chicago Tribune, 15 April, viewed 7 January 2017: http://www.chicagotribune.com/ business/ct-mcdonalds-executive-compensation-0416-biz-20160415-story.html.

Cicero M (1928) The Verrine Orations; translated by L. H. G. Greenwood Harvard University Press: Cambridge. MA, original work published c. 70 BCE.

Cook T (2016) A message to the Apple community in Europe. 30 August, viewed 7 January 2017, http://www.apple.com/mt/customer-letter/.

Equal Employment Opportunity Commission. Fiscal year 2016 highlights, viewed 25 March 2017, https://www.eeoc.gov/eeoc/newsroom/wysk/2016_highlights. $\mathrm{cfm} /$.

Friedman M (1970) "The social responsibility of business is to increase its profits." The New York Times Magazine, 13 September. Viewed 28, June 2016, http:// www.colorado.edu/studentgroups/libertarians/issues/friedman-soc-resp-busi ness.html.

Friedman M (2002) Capitalism and Freedom. University of Chicago Press: Chicago, IL.

Fuerstein M (2015) Contesting the market: An assessment of capitalisms threat to democracy. In: Rangan S (ed). Performance and Progress: Essays on Capitalism, Business, and Society. Oxford University Press: Oxford, United Kingdom.

Kadet JM (2016) "No, US taxpayers will not pay Apples $\$ 14.5$ billion Irish tax bill." Forbes, 30 September, viewed 7 January 2017, http://www.forbes.com/sites/ janetnovack/2016/09/13/no-u-s-taxpayers-wont-pay-apples-14-5-billion-irishtax-bill/\#378598a713af.

MacIntyre A (1984) After Virtue, 2nd ed., University of Notre Dame Press: Notre Dame, IN.

Marx K and Engels F (1988) The Communist Manifesto. International Publishers Co: New York.

McDonald's Average Wage. (2016) https://www.glassdoor.com/Hourly-Pay/ McDonald-s-Hourly-Pay-E432.htm, viewed 29 June.

McDonald's Corporation - Form 10- K. (2015) http://www.aboutmcdonalds.com/ content/dam/AboutMcDonalds/Investors\%202/2015\%20Annual\%20Report. pdf, viewed 6 June.

NASDAQ 2017. (2017) http://www.nasdaq.com/symbol/mcd/dividend-history and http://www.nasdaq.com/symbol/mcd/ownership-summary, viewed 7 January.

"National Minimum Wage and National Living Wage" 2017. (2017) https://www. gov.uk/national-minimum-wage-rates, viewed 10 January.

Nozick R (2000) The entitlement theory. In: Solomon RC and Murphy MC (eds). What is Justice: Classic and Contemporary Readings. Oxford University Press: New York.

Piketty T and Saez E (2014) Inequality in the long run. Science; 344 (6186): 838-843.
Rawls J (1999) A Theory of Justice. Harvard University Press: Cambridge, MA.

Robinson S (2016) The Practice of Integrity in Business. Palgrave Macmillan: London.

Securities and Exchange Commission. (2015) McDonald's Corporation, Rule 14a8, no action letter, viewed 10 January 2017, https://www.sec.gov/divisions/ corpfin/cf-noaction/14a-8/2015/alisonfaith031815-14a8.pdf.

Seneca LA (1989) Seneca Moral Essays; translated by JW Basore Harvard University Press: Cambridge, MA, original published c. 65 AD.

Smith A (1776) An inquiry into the nature and causes of the wealth of nations, viewed 2 January 2017, http://www.econlib.org/library/Smith/smWN.html.

Smith A (2002) The Theory of Moral Sentiments, 6th edn. Cambridge University Press: New York, original 6th edn. published 1790.

Tomasi J (2012) Free Market Fairness. Princeton University Press: Princeton, NJ. Wallace J (1978) Virtues and Vices. Cornell University Press: Ithica, NY.

Williams B (1985) Ethics and the Limits of Philosophy. Harvard University Press: Cambridge, MA.

Wordnik.com. (n.d.) "Integrity," viewed 30 June 2016, http://www.wordnik.com/ words/integrity.

Worstal T (2016) "U.S. wages are rising, McDonald's rolls out self service - fight for \$15's got a problem, doesn't it?” Forbes, 18 November, viewed 7 January 2017. http://www.forbes.com/sites/timworstall/2016/11/18/us-wages-are-rising-mcdo nalds-rolls-out-self-service-fight-for-15 s-got-a-problem-doesnt-it/ $\# 1 \mathrm{a} 46 \mathrm{~b} 2 \mathrm{~b} 732 \mathrm{ed}$

\section{Data availability}

Data sharing is not applicable to this article as no datasets were generated or analysed.

\section{Additional information}

Reprints and permission information is available at http://www.palgrave-journals.com/ pal/authors/rights_and_permissions.html

How to cite this article: Bauman D (2017) Integrity and justice: what is required of free market participants? Palgrave Communications. 3:17046 doi: 10.1057/palcomms.2017.46.

Publisher's note: Springer Nature remains neutral with regard to jurisdictional claims in published maps and institutional affiliations.

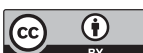

This work is licensed under a Creative Commons Attribution 4.0 International License. The images or other third party material in this article are included in the article's Creative Commons license, unless indicated otherwise in the credit line; if the material is not included under the Creative Commons license, users will need to obtain permission from the license holder to reproduce the material. To view a copy of this license, visit http://creativecommons.org/licenses/by/4.0/

(C) The Author(s) 2017 